\title{
Size Dependence of Energy Required for Cassava Grating
}

\author{
Asinyetogha H. Igoni ${ }^{1} \&$ Isoteim Fubara-Manuel ${ }^{1}$ \\ ${ }^{1}$ Department of Agricultural and Environmental Engineering, Faculty of Engineering, Rivers State University of \\ Science and Technology, Nigeria \\ Correspondence: Asinyetogha H. Igoni, Department of Agricultural and Environmental Engineering, Faculty of \\ Engineering, Rivers State University of Science and Technology, P M B 5080, Port Harcourt, Nigeria. Tel: \\ 234-802-3123-471. E-mail: ahigoni@yahoo.com
}

Received: May 26, 2016

Accepted: June 23, 2016

Online Published: July 4, 2016

doi:10.5539/eer.v6n2p1

URL: http://dx.doi.org/10.5539/eer.v6n2p1

\begin{abstract}
An investigation was conducted into the energy required for grating cassava tubers of varying sizes. The tuberous roots of cassava that naturally occur in lengths of between 15 and $100 \mathrm{~cm}$ were cut and separated into groups of five different sizes $(343.2 \mathrm{~mm}, 228.8 \mathrm{~mm}, 171.6 \mathrm{~mm}, 85.8 \mathrm{~mm}$ and $42.9 \mathrm{~mm})$. Equal masses of $10 \mathrm{~kg}$ of these size categories were respectively grated down to a particle size of $1.5 \mathrm{~mm}$, with a grating machine powered by a 5.4hp diesel engine. A tachometer was used to measure the speed of rotation of the engine during the operation, from where the power transmitted to the grater was computed. It was found that the size of the cassava affected the speed of the engine in an inverse proportionality relationship; and the reducing sizes resulted in reduced times and energies required for the operation. The experimental values were related to the already known laws of comminution, using Kick and Bond's formulae. Models were formulated for the various relationships using Microsoft Chart Editor. It was discovered that, although the energy values estimated using the laws were higher than experimental values, the values obtained using Kick's law were a better approximation. On the overall, this study showed that the smaller the size reduction ratio, by a reduction of the feed size of cassava before grating, the lesser the energy that would be expended during the grating operation.
\end{abstract}

Keywords: cassava size, grating, energy, comminution, gari, throughput

\section{Introduction}

\subsection{Energy Situation in Nigeria}

Energy is ordinarily the capacity of a person or machine to do work; and work must continuously be done for the sustenance of human activities and systems. Indeed energy is now a global concern as the totality of man's activities strictly depends on it, despite its being in relatively very short supply. Energy is fundamental to the continued survival of a people: Their socio-economic and indeed political development; prosperity for future growth, including the rate of growth of infrastructural facilities; level of agricultural and industrial production; state and level of delivery of social services; etc. The energy requirement of these different societal structures/components is strictly dependent on population, that is, as population increases more energy should be available for use. But this does not seem to be the case, even globally, as there has been international outcry for energy generation and conservation; and the need for more and more energy to meet an ever increasing world population. This energy demand-supply imbalance has elicited several forms of alternative energy and energy conservation proposals and systems; but yet energy has constantly eluded man.

The Nigerian energy situation is a very pathetic case. Between 2006 and 2016 the population of the country has increased by about 25\%, rising from 140,003,542 in 2006 (Nigerian 2006 Census Figure) to an estimated 186,515,618 in 2016 (Nigeria Population 2016, May 23, 2016; 2:16am); but the energy growth has been on the decline. In 2016, available power has been fluctuating between 2,300 MW and 4,400 MW (Information Nigeria, 2016, and Sahara Reporters, 2016, May 23, 2016), recording a total collapse to zero megawatts (Sahara Reporters, 2016) at some point in time. Nigeria is definitely embroiled in a seemingly unending energy crises and needs help. This is why Ilori (2001) said "in Nigeria, domestic demand for energy is growing while total domestic production is declining as a result of poor performance and low output of our refineries and power generating plants". This energy situation, where large population is chasing little amount of energy, has expectedly resulted in very high cost of energy in the country. This high cost of energy is directly impacting 
negatively on the productive sectors of the nation's economy, including agriculture. In fact, as at the time of compilation of this report, by May 18, 2016, there was a nation-wide industrial action by the Nigerian Labour Congress protesting price hike in premium motor spirit from $\$ 86.50$ to $\$ 145.00$ (i.e. from USD0.44 to USD0.73, at the official exchange rate of $\$ 199.00$ for $\$ 1.00$ ).

In very recent times Nigeria has expressed its desire to embark on mechanized agriculture. This was shown by Igoni \& Ayotamuno (2016) when they stated that there are indications that the Nigerian government is concerned about its backwardness in agriculture, and is taking steps to upgrade agricultural performance, especially from the prism of mechanization. They declared that there was soon going to be what they referred to as a mechanization boom in the country. Any effort to mechanize agriculture would automatically translate to an increased demand for energy; and one of the energy-input areas in agriculture in Nigeria is the processing of cassava.

\subsection{Cassava Production in Nigeria}

The cassava plant (manihot esculenta, crantz) is a tuberous root crop that is popularly used as a major food item across the various peoples of Nigeria. Several researchers have referred to it as the third most important staple food in the tropics after rice and maize (Cock, 1985), but by 1992, it was said to be the second most important after maize alone (Nweke, 1992). Howeler, Oates \& Allem (2001) say cassava is a major food and industrial crop in tropical and subtropical Africa, Asia and Latin America. What is striking here is that cassava is a useful food and industrial product in the lives of the Nigerian people. Cassava is said to be native to South/Latin America, but introduced to Asia in the $17^{\text {th }}$ century and later to Africa in the Congo basin by the Portuguese at about 1558 (International Institute of Tropical Agriculture, IITA, 2013 and Ugwu, 1996). It was introduced to Southern Nigeria during the slave trade (Adeniji et al, 2005).

As at 2007 the global production of cassava was 228 million tons and Africa contributed 52\%, out of which Nigeria produced 46 million tons (IITA, 2013). This is slightly different from the report of Adekanye, Ogunjimi \& Ajala (2013) that Nigeria produces about 45 million tonnes as at 2009, which accounted for about $19 \%$ of total world production of the product. However, whatever figures are available, the central point is that Nigeria is currently the world's largest producer of cassava (United States Agency for International Development, USAID, 2013; IITA, 2013). Nigeria has a capacity three times more than Brazil and almost twice that of Indonesia and Thailand. In fact, the production by all other African countries - the Democratic Republic of the Congo, Ghana, Madagascar, Mozambique, Tanzania and Uganda - is relatively insignificant (Ashaye, Couple, Fasoyiro \& Adeniji, 2005).

The crop is grown throughout the year, with about $90 \%$ of the producers being small-scale farmers, as is the case with general agricultural production in the country (Igoni \& Ayotamuno, 2016). This may account for the 2002 Food and Agriculture Organisation estimates that, despite the massive cassava production in Africa, she exports only one million ton of cassava annually. This can also be attributed to the inefficient utilization of energy (Food and Agriculture Organisation, FAO, 2002). The Nigerian government, in a presidential initiative of July 2002, proposed to increase production of cassava to about 150 million tonnes, promote self-sufficiency and consequently reduce rice and wheat imports by 2010 through intensive mechanization of the production and processing activities (HarvestPlus, 2012). Although this initiative suffered a set-back, there is still the need for mechanization of cassava production and processing activities.

Cassava is rich in carbohydrates, calcium, vitamins $\mathrm{B}$ and $\mathrm{C}$, and essential minerals, although nutrient composition differs according to variety and age of the harvested crop, and soil conditions, climate, and other environmental factors during cultivation. It is a valuable source of cheap calories arising from its starchy, thickened and tuberous roots' nature. The leaves and tender shoots of cassava are consumed as vegetables (Krochmal \& Hahn, 1991). Despite the food value of cassava, its derivatives and starch are applicable in many types of products such as confectionery, sweeteners, glues, plywood, textiles, paper, biodegradable products, monosodium glutamate, and drugs. Cassava chips and pellets are used in animal feed and alcohol production (IITA, 2013).

\subsection{Energy-Use in Cassava Processing}

There are different operations involved in the processing of cassava into its usable end products. These operations individually require different levels of energy to be carried out. In the circumstance of Nigeria's desire to undertake mechanization of its agricultural operations, especially cassava processing, the energy that would be consumed by the cassava processing operations will be of primary concern. Some previous investigators have undertaken some aspects of this exercise. Odigboh (1997) developed a method for estimating manual energy input in agricultural operations; and Jekanyinfa \& Olajide (2007) investigated energy use pattern 
in selected cassava processing mills in South-western Nigeria and developed a predictive model to estimate and optimize the energy demand of each unit operation for different selected cassava products.

Grating is one the unit operations in processing cassava tubers into gari. After the tubers are peeled and washed, they are put into the grater to be mashed. Usually the tubers range from $15-100 \mathrm{~cm}$ in length and weigh between 0.5-2.0kg (Knoth, 1993). Earle (1983) and Henderson and Perry (1966) opine that grinding is an inefficient operation requiring so much energy. There is the need, therefore, for appropriate energy rating of systems in order to optimize energy use.

In their investigation, Jekanyinfa \& Olajide (2007) found that grating of cassava for gari production used over $70 \%$ of the total energy consumption for the entire gari making process. However, Ibrahim and Gaji (2016) identified frying as the most energy intensive operation in gari making processes. The latter finding is somewhat strange because, for any given product, more energy is required to overcome inter-particular forces and disintegrate the material than to extract moisture from the particles. Generally, Wang (2009) states that "the food industry is one of the energy-intensive industries and lacks information on energy conservation and conversion technologies".

\subsection{Unit Operations in Cassava Processing}

There are several unit operations involved in the processing of cassava into any of its usable end products, in this case gari, of which grating is one. Figure 1 is a flowchart of these unit operations.

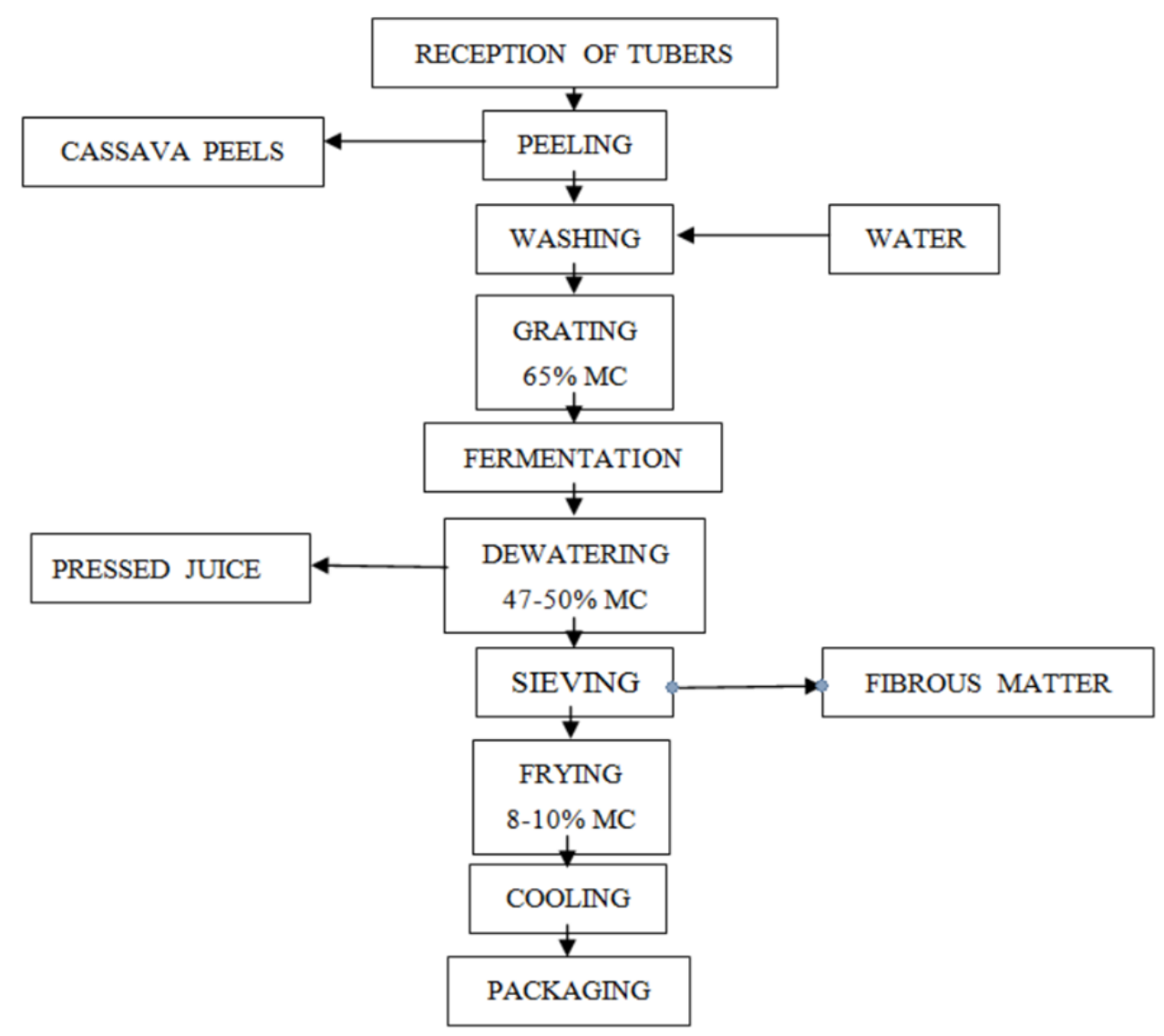

Figure 1. Simplified Flowchart of Unit Operations in Cassava Processing for Gari Production

Adopted from Igoni, 1991

\subsubsection{Cassava Grating Operation}

Grating is a size-reduction activity, involving the breakdown of cassava tuberous roots into smaller particles. When cassava is harvested, it undergoes physiological deterioration after 3 to 4 days; and thereafter microbial deterioration sets in, as the former phase of deterioration would have provided conditions favourable for microbial infestation. This propensity of the product to deteriorate fast immediately after harvest, makes it imperative for it to be processed before deterioration sets in. Also, upon harvest, cassava is massive and contains a high quantity of 
moisture, estimated as 70\%, and both the roots and leaves contain varying amounts of cyanide, which is toxic to human health (Hahn, 1989). These features of cassava make its use difficult. Aside from the tedium and cost in transporting its mass from one place to another, there is the problem of storage and edibility. Therefore, there is the necessity for processing of the product.

The processing of cassava into gari involves, among other things, the pulverization of the tuberous roots into fine particles of about $1.5 \mathrm{~mm}$ (Opandoh, 2014) and the moisture content reduced to between 9 and 10\% (Hahn, 1989; Igoni, 1991). The cyanide content also is reduced to less than $10 \%$, in keeping with the specifications of the Standard Organization of Nigeria and National Food and Drug Administration Council (Cassava Millers, 2016). Particle size reduction enhances flavour level, as particle size influences colour and taste. Colour can be enriched if particle size and shape are uniform, and, through particle size control, certain colour wavebands can be blocked out in favour of a specific band like red or yellow (Heldman, 1975). Heldman further states that grinding grain for stock increases digestibility and palatability. It is, therefore, inevitable that grating is a veritable operation in the processing of cassava for consumption as gari.

The grating of cassava involves mainly grinding of the product, wherein the peeled and washed tubers are put into the machine in their original sizes, except the original size is longer or bigger than the inlet hopper of the machine, then the tuber is first cut before being put into the machine, strictly for convenience of processing. In some instances the tubers are put into the machine on its longitudinal axis, thereby avoiding cutting. Earle (1983) says in some operations involving very large particle sizes, cutting is essentially used to reduce the product sizes to a level suitable for further processing. Cutting of the cassava is expected to aid its grinding (grating), which reduces the product sizes by fracturing them. The shearing and compressive action of the rolling drum of the grater on the cassava tubers induces stress in them, which is initially absorbed internally as strain energy. When the strain energy exceeds critical limit of the internal stress bearing capacity of the material, rupture occurs as the material gives off its stored energy.

\subsection{Theoretical Bases for Energy Estimation}

Generally, the energy required for grinding depends on the hardness and friability of the material (Earle, 1983). This energy is used to create new surface areas and some lost as heat. So, it is important to apply an amount of energy that would slightly exceed the minimum required to cause rupture of the material. The computation of this energy is somewhat cumbersome. However, there are theoretical bases for the estimation of energy use in any size reduction operation. A general formulation relating comminution energy and the product size from a given feed size was proposed by Walker, Lewis, McAdams \& Gilliland (1937) in Jankovic, Dundar \& Mehta (2010), thus:

$$
d E=-C\left(d x / x^{n}\right)
$$

Where

E - net specific energy, $\mathrm{kWh} / \mathrm{t}$

$\mathrm{C}$ - constant related to the material

$\mathrm{X}$ - characteristic dimension of the product , $\mathrm{m}$

$\mathrm{n}$ - an exponent

This is probably why Henderson \& Perry (1966) say that "the energy required" for a size reduction operation "must be related to some function of the initial and reduced particle"; and Earle (1983) state that the theories for the estimation of energy required in size reduction are based on the assumption that the energy required to produce a change $d L$ in a particle of a typical size dimension $L$ is a simple power function of $L$.

$$
\text { i.e. } \quad d E / d L=K L^{n}
$$

where dE - differential energy required, $\mathrm{kWh}$

$\mathrm{dL}$ - change in typical length, $\mathrm{m}$

$\mathrm{L}$ - Initial length dimension of the material, $\mathrm{m}$

$\mathrm{K}, \mathrm{n}$ - constants

This general formulation, was based on some empirical models previously developed by earlier Researchers for different materials and degrees of grinding. Rittinger (1867) was the first to develop an expression for energy required in size reduction, on the assumption that energy consumed in size reduction is directly proportional to the new surface area formed, such that in equation (2), $n=-2$, thus:

$$
E=K_{R} f_{c}\left(1 / L_{2}-1 / L_{1}\right)
$$




$$
K=K_{R} f_{c}
$$

Where

$\mathrm{K}_{\mathrm{R}}$ - Rittinger's constant

$f_{c}$ - crushing strength of the material

On the other hand, Kick (1885) stated that the energy required to reduce a material is directly proportional to the size reduction ratio, $d L / L$, such that in equation $(2), \mathrm{n}=-1$, thus:

$$
\begin{array}{r}
E=K_{K} f_{c} \log _{e}\left(L_{1} / L_{2}\right) \\
K=K_{K} f_{c}
\end{array}
$$

Where

$\mathrm{K}_{\mathrm{K}}$ - Kick's constant

Then Bond (1952) developed an equation on the assumption that the work input is proportional to the dimension of the crack produced upon particle breakage. This equals the work represented by the product minus that represented by the feed. Graphically, the size in microns which $80 \%$ passes is selected as the criterion of particle size. In relation to equation (2), Bond assumed an intermediate course between the ' $n$ ' values of Rittinger and Kick, in which $\mathrm{n}=-1.5$.

The following equation was developed.

$$
\begin{gathered}
E=10 E_{i}\left[\left(1 / \sqrt{ } L_{2}\right)-\left(1 / \sqrt{ } L_{1}\right)\right] \\
K=5 E_{i}
\end{gathered}
$$

Where $E_{i}$ is referred to as the Bond Work Index and is used to denote the resistance the material offers to crushing and grinding. It is quantifiably the kilowatt-hours per short ton required to reduce the material from a theoretically infinite feed size to a size where $80 \%$ passes through a 100 microns sieve (Earle, 1983; Kumar, 2011). The Work Index is expressed in terms of the reduction ratio, $q$,

Where

$$
q=L_{1} / L_{2}
$$

So

$$
E=E_{i}\left[100 / L_{2}\right]^{1 / 2}\left[1-\left(1 / q^{1 / 2}\right)\right]
$$

The fundamental basis for these laws of comminution is that the material being reduced is brittle. Empirical evaluations have shown that these laws find application in grinding to different product sizes. Whereas Rittinger's law applies better to the size reduction of fine powders, Kick's law suits the reduction of coarse particles. On the other hand, Bond's law applies to fine, medium and coarse grinding. Yet Hukki (1975) observes that the laws of Rittinger, Kick and Bond are all relevant to the relationship between energy and particle size, as, according to him, the probability of breakage in comminution is high for large particles, and rapidly diminishes for fine sizes. Following Hukki's proposition, Morrell (2004) proposed a model to modify Bond's law (Kumar, 2011) thus:

$$
E=K_{m} M_{i}\left[\left(1 /\left(L_{2}^{f\left(L_{2}\right)}\right)-\left(1 /\left(L_{1}^{f\left(L_{1}\right)}\right)\right]\right.\right.
$$

Where

$M_{i}$ - material index related to its breakage property

$\mathrm{K}_{\mathrm{m}}$ - A constant to balance the units of the equation

This relationship has been found validly applicable in the size range of $0.1-100 \mathrm{~mm}$. From all these relationships used for the prediction of energy requirement for reducing the size of a material, we find that the energy use in a size reduction operation is a function not only of the internal stress resistance characteristics of the material, but also of the original size dimension and required reduced dimension of the material.

\subsection{Research Objective}

Comminution theories have shown that the energy required for a given size reduction operation is a function of the original and desired (final) size characterization of the product being reduced. Therefore, this paper examines the effect of varying initial sizes of cassava tubers during grating on the energy required for the operation, in order to establish what size range that would be most appropriate as the feed size; and to relieve the grating process of inherent inefficiencies and thus enhance throughput. 


\section{Materials and Method}

\subsection{Experimental Procedure}

The materials used for this work include a mass of cassava tubers, kitchen knives, aluminium basins, a regular village cassava grating machine, tachometer, $50 \mathrm{~cm}$-rule, stop watch and a weighing balance. The grater has its grating element as a cylindrical drum rapped with a metal sheet perforated from underneath, providing a jagged or rasping surface. It was $32 \mathrm{~cm}$ long, $30 \mathrm{~cm}$ in diameter and mounted with a shaft on its horizontal axis in-between bearings in the machine compartment. It was driven by a $5.4 \mathrm{hp} \mathrm{diesel} \mathrm{engine.}$

The peeled cassava tubers of approximately uniform thickness of $40 \mathrm{~mm}$ were cut and sorted into different size ranges by length. Their lengths were measured with the $50 \mathrm{~cm}$-rule. Five size classifications of $343.2 \mathrm{~mm}$, $228.8 \mathrm{~mm}, 171.6 \mathrm{~mm}, 85.8 \mathrm{~mm}$ and $42.9 \mathrm{~mm}$ were used for the experiment. Two able-bodied and energetic men were involved in the cutting of the tubers into the various sizes. Equal masses of $10 \mathrm{~kg}$ each of these different size ranges were measured using the aluminium basins and weighing balance. The engine speed was first measured at no-load using the tachometer. Thereafter, the machine was loaded with the tubers, one size category after another, and grated. In each case, tachometer readings were taken under load; and the stopwatch was used to measure the time of completion of grating of each category.

\subsection{Power determination}

The power $(\mathrm{P})$ used during the operations was determined as a function of the speed of rotation of the engine $(\mathrm{n})$ and the torque $(\mathrm{T})$ developed, using the following relationships.

$$
P=2 \pi n T / 60
$$

The torque transmitted by the engine is given as:

$$
T=W r
$$

where: $\mathrm{W}$ - weight of grating drum, $\mathrm{N}$

$r$ - radius of grating drum, $m$

Combining equations (12) and (13) gives the general power relationship as:

$$
P=2 \pi n W r / 60
$$

\subsection{Energy-Use Determination}

\subsubsection{Manual Energy in Cutting}

The empirical energy used for the size reduction operations was determined in two phases, viz i) manual energy expended in cutting the tubers into sizes: this was done using the method proposed by Odigboh (1997) as adopted by Jekayinfa \& Olajide (2007). Odigboh says that at the maximum continuous energy consumption rate of $0.30 \mathrm{~kW}$ and conversion efficiency of $25 \%$, the physical power output of a normal human labour in tropical climates is approximately $0.075 \mathrm{~kW}$ sustained for an $8-10 \mathrm{~h}$ work day. Any other factor affecting manual energy input was considered ancillary, insignificant and, therefore, negligible. The time spent on the manual operation, in this case the cutting of the tubers into different size categories, was recorded, including idle times. The expression developed by (Odigboh, 1997) is of the form:

$$
E_{m}=0.075 x N x T_{a}
$$

where: $\mathrm{E}_{\mathrm{m}}$ - manual energy used for the cutting operation, $\mathrm{kWh}$

0.075 - the average power of a normal human labour in $\mathrm{kW}$

$\mathrm{N}$ - number of persons involved in an operation

$\mathrm{T}_{\mathrm{a}}$ - useful time spent to accomplish a given task (operation), $\mathrm{h}$

2.3.2 Energy expended by the machine under no-load

This is defined thus:

$$
E_{n}=P_{n} x t^{i}
$$

where: $P_{n}$ - power developed by the machine under no-load condition $(k W)$

$\mathrm{t}^{\mathrm{i}}$ - a predetermined time, translated to a per unit hourly time (hr)

\subsubsection{Total Energy Expended by Machine}

This is given as: 


$$
E_{t}=P_{t} x t
$$

where: $\mathrm{P}_{\mathrm{t}}$ - total power developed by machine during the operation $(\mathrm{kW})$

$\mathrm{t}$ - time for grating (hr)

Therefore, the effective energy, $\mathrm{E}_{\mathrm{e}}$, for the operation was computed with the expression derived by combining equations (15), (16) and (17), as follows:

$$
\begin{gathered}
E_{e}=E_{m}+\left[\left|E_{n}-E_{t}\right|\right] \\
E_{e}=\left[0.075 x N x T_{a}\right]+\left[\left|\left(P_{n} x t^{i}\right)-\left(P_{t} x t\right)\right|\right]
\end{gathered}
$$

\subsection{Specific Energy Determination}

The specific energy, $E_{s}$, is used to determine whether the energy-use for the operation is either high or low. It is defined as the ratio of the effective energy expended during the grating operation to the total surface area of the cassava grated.

$$
E_{s}=E_{e} / A_{s}
$$

For the purpose of this study, $\mathrm{E}_{\mathrm{s}}$ varies directly as $\mathrm{E}_{\mathrm{e}}$, since $\mathrm{A}_{\mathrm{s}}$ is a constant for the different size categories.

\subsection{Application of the Laws of Comminution}

For cassava grating, which could be described as coarse grinding, as the required final particle size is coarse, the applicable comminution laws are Kick and Bond. The respective constants were determined using the empirical energy determined from equation (18b). Thereafter, the energy estimates from Kick and Bond's laws were determined using equations (5) and (7) respectively.

\section{Results}

Preliminary measurements show that the weight and diameter of the grating element are respectively $5.84 \mathrm{~kg}$ and $0.3 \mathrm{~m}$. Time used to operate the machine at no-load was about 1 minute 55 seconds. Although the manufacturer's speed rating of the engine was $3600 \mathrm{rpm}$, under no-load condition, the engine actually ran at 3020rpm. Using equation (13) the torque delivered by the rotating grating drum was calculated as $8.6 \mathrm{~N}-\mathrm{m}$; and with equations (14) the power generated at no-load was computed as $2.720 \mathrm{~kW}$. Now, since all the parameters in the determination of the no-load power transmitted by the engine are constants, especially that no matter for how long the engine ran under no-load, whatever speed fluctuations would be negligible, then the no-load power could be considered on a unit time basis. Therefore, for 1hour, the energy expended under no-load, using equation (16) would be $2.720 \mathrm{kWh}$. The results obtained from the experimentation and calculations made using applicable equations in section 3.0, especially equation (18b) to determine the effective energy required for the operation, are presented in Tables 1 and 2. Table 3 shows energy-use determined by the application of Kick and Bond's law.

Table 1. Manual energy expended during cutting of the tubers

\begin{tabular}{lllll}
\hline $\begin{array}{l}\text { S/No. of } \\
\text { operations }\end{array}$ & $\begin{array}{l}\text { Length } \\
\text { of tubers } \\
(\mathrm{mm})\end{array}$ & $\begin{array}{l}\text { No. of } \\
\text { persons }\end{array}$ & $\begin{array}{l}\text { Time spent } \\
\text { in cutting } \\
\text { (h) }\end{array}$ & $\begin{array}{l}\text { Manual } \\
\text { energy used } \\
(\mathrm{kWh})\end{array}$ \\
\hline 1 & 343.2 & 2 & 0.037 & 0.006 \\
2 & 228.8 & 2 & 0.058 & 0.009 \\
3 & 171.6 & 2 & 0.067 & 0.010 \\
4 & 85.8 & 2 & 0.083 & 0.012 \\
5 & 42.9 & 2 & 0.136 & 0.021 \\
\hline
\end{tabular}

Table 2. Effective energy-use during grating of the cassava tubers

\begin{tabular}{lllllll}
\hline $\begin{array}{l}\text { S/No. of } \\
\text { operations }\end{array}$ & $\begin{array}{l}\text { Length } \\
\text { of tubers } \\
(\mathrm{mm})\end{array}$ & $\begin{array}{l}\text { Engine } \\
\text { speed } \\
(\mathrm{rpm})\end{array}$ & $\begin{array}{l}\text { Power } \\
(\mathrm{kW})\end{array}$ & $\begin{array}{l}\text { Time of } \\
\text { grating } \\
(\mathrm{h})\end{array}$ & $\begin{array}{l}\text { Effective } \\
\text { energy-use } \\
(\mathrm{kWh})\end{array}$ & $\begin{array}{l}\text { Throughput } \\
(\mathrm{kg} / \mathrm{hr})\end{array}$ \\
\hline 1 & 343.2 & 2,700 & 2.433 & 0.0931 & 0.293 & 107.4 \\
2 & 228.8 & 2,760 & 2.487 & 0.0806 & 0.243 & 124.1
\end{tabular}




$\begin{array}{lllllll}3 & 171.6 & 2,790 & 2.514 & 0.0760 & 0.216 & 131.6 \\ 4 & 85.8 & 2,810 & 2.532 & 0.0561 & 0.200 & 178.3 \\ 5 & 42.9 & 2,830 & 2.550 & 0.0242 & 0.191 & 413.2\end{array}$

Table 3. Determination of energy required using Kick and Bond's laws

\begin{tabular}{llllll}
\hline $\begin{array}{l}\text { S/No. of } \\
\text { operations }\end{array}$ & $\begin{array}{l}\text { Length } \\
\text { of tubers } \\
(\mathrm{mm})\end{array}$ & $\begin{array}{l}\text { Engine } \\
\text { speed } \\
(\mathrm{rpm})\end{array}$ & $\begin{array}{l}\text { Time of } \\
\text { grating } \\
(\mathrm{h})\end{array}$ & $\begin{array}{l}\text { Kick's } \\
\text { value } \\
(\mathrm{kWh})\end{array}$ & $\begin{array}{l}\text { Bond's } \\
\text { value } \\
(\mathrm{kWh})\end{array}$ \\
\hline 1 & 343.2 & 2,700 & 0.0931 & 0.293 & 0.293 \\
2 & 228.8 & 2,740 & 0.0806 & 0.271 & 0.289 \\
3 & 171.6 & 2,770 & 0.0760 & 0.255 & 0.285 \\
4 & 85.8 & 2,810 & 0.0561 & 0.218 & 0.272 \\
5 & 42.9 & 2,830 & 0.0242 & 0.181 & 0.255 \\
\hline
\end{tabular}

\section{Discussion}

The data in the Tables are represented graphically in Figures 2-8. Figure 2 shows the net energy expended on the grating of the cassava as a function of the cassava sizes. It is called the effective grating energy, as it is the actual energy that varies with the particle size. The trend is perfectly represented by a polynomial function of order two, as in equation (20), with a correlation percentage of 99.6 .

$$
E_{e}=7 E-07 C_{s}^{2}+7 E-05 C_{s}+0.1871
$$

where $\mathrm{C}_{\mathrm{s}}$ is the characteristic size (length) dimension of cassava in millimetres.

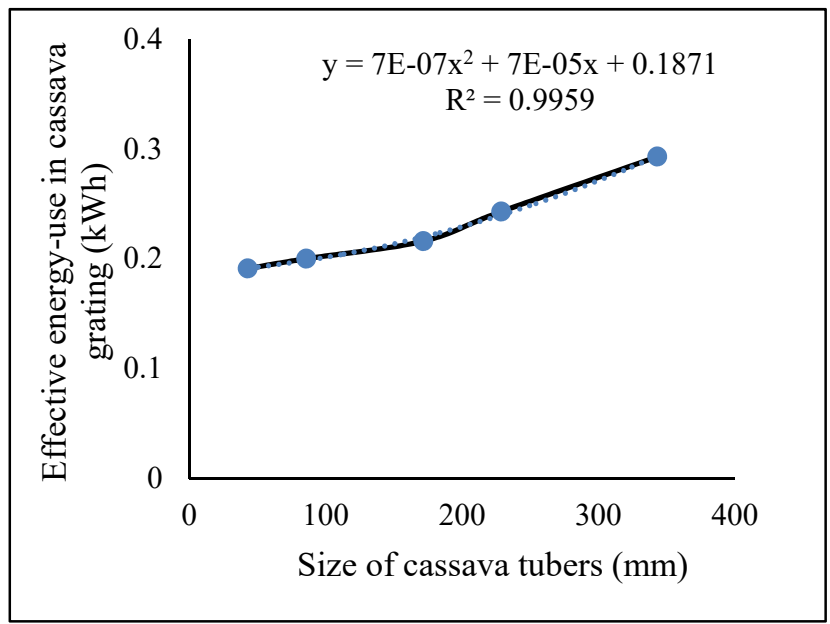

Figure 2. Energy-use variation with size of cassava during grating

The relationship depicts a more or less arithmetic increase in energy use with size of cassava at smaller sizes and a geometric increase at higher sizes. It means that, apart from the revelation that the energy-use is affected by the size of the cassava, in that as the size of the cassava reduces the energy required also reduces and vice versa, a more stable energy utilization is achieved with smaller particle sizes than with bigger ones.

In Figure 3, a perfect logarithmic function, as in equation (21), describes the relationship between size of cassava and energy required for its grating, computed using equation (5) with the maximum experimental figure as the initial particle size and the desired particle size of $1.5 \mathrm{~mm}$ as the final particle size, to obtain the Kick's constant as an approximation.

$$
E_{k}=0.0538 \ln \left(C_{s}\right)-0.0216
$$




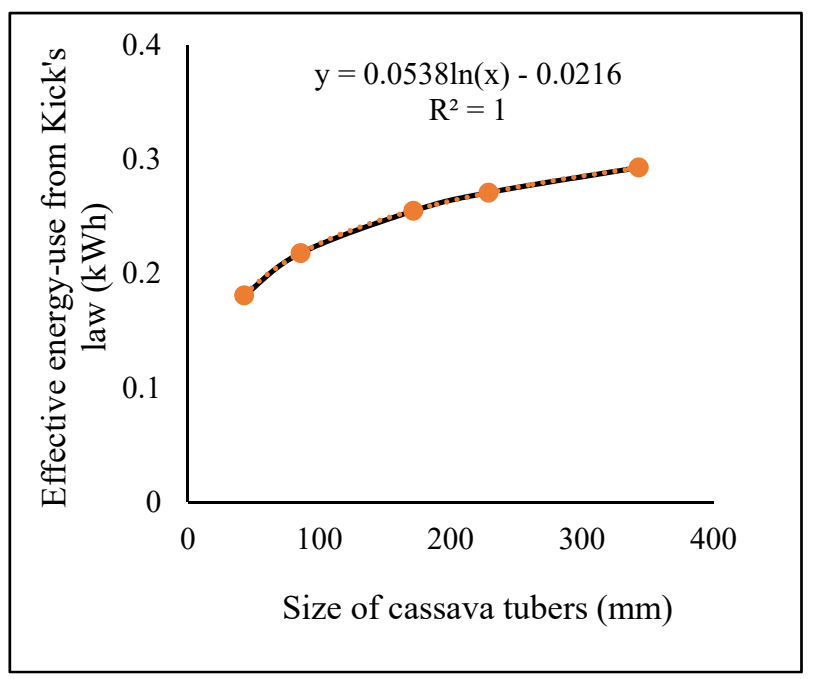

Figure 3. Energy-use determination by Kick's law

The derivation of this logarithmic function gives further credence to the original empirical formulation by Kick (equation 5). Equation (5) considers both the initial and final characteristic dimension and explains that as the ratio of the initial size to the final size increases the energy required for grating also increases, thus establishing the direct proportionality between energy requirement and size reduction ratio. This is similar to the model equation (21), which shows that the larger the initial particle size, the more the energy required. This experimental equation (21) considers a common final particle size for all categories of the initial size. A striking similarity in these equations is in the marginality of the incremental energy required for progressive size reduction ratios.

There is a marked deviation of energy-use values obtained using Bond's law from those obtained experimentally (Table 3). Although the energy required, determined with Bond's equation ((7), progressively reduced with reducing cassava size (Figure 4), all the Bond's values are in the neighbourhood of the first experimental feed size $(343.2 \mathrm{~mm})$ which is $0.293 \mathrm{kWh}$, as they are higher than the energy value for the next feed size. This shows that the Bond's values are not representative of the energy requirement of cassava in processing.

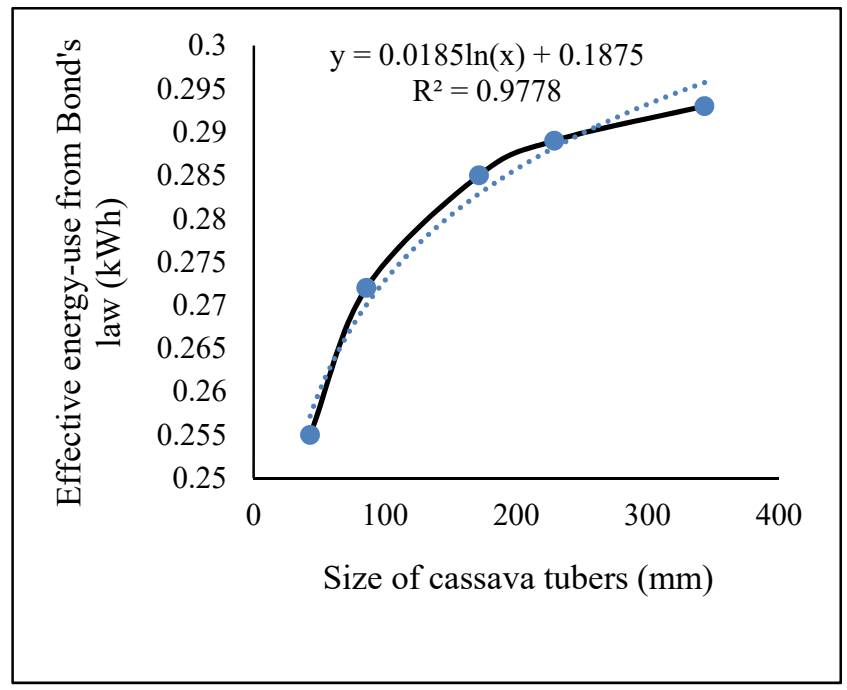

Figure 4. Energy-use determination by Bond's law

Equation (22) is a mathematical representation of the relationship between the cassava feed sizes and the derived energy-use from Bond's law.

$$
E_{B}=0.0185 \ln \left(C_{s}\right)+0.1875
$$


where: $\mathrm{E}_{\mathrm{B}}$ - Energy use from Bond's law

The derivation from the curve of Figure 3 is further replicated in Figure 5, which relates the time used for the grating operation to the size of cassava, even though the latter bears physical resemblance with Figure 4. Again a logarithmic function, equation (23), is derived from this relationship.

$$
t_{g}=0.0322 \ln \left(C_{s}\right)-0.0927
$$

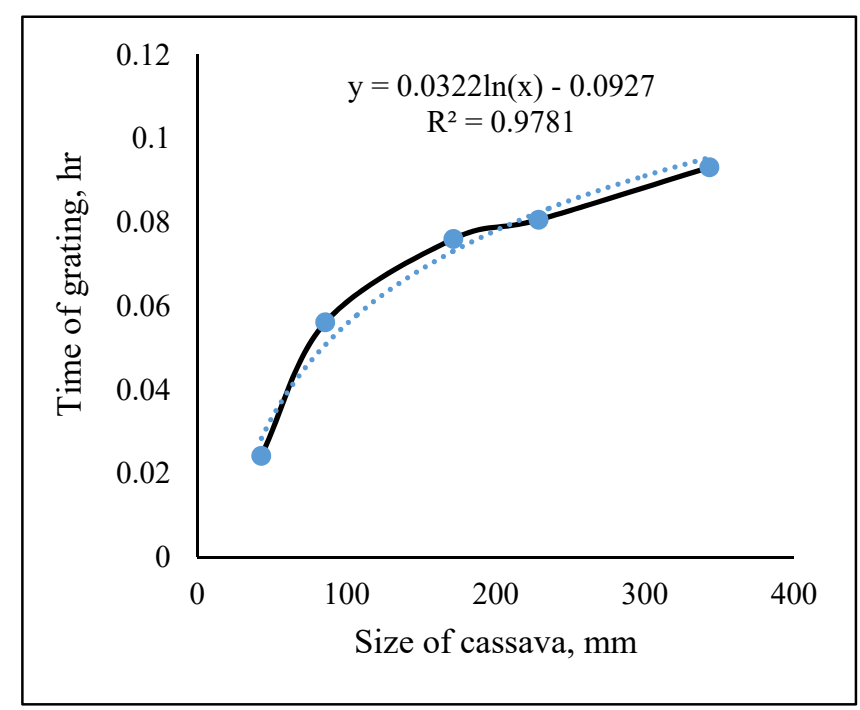

Figure 5. Effect of cassava size on time of grating

It shows that the cassava breakdown is more rapid or faster at smaller particle sizes. At the same time, relating equation (23) to previous equations, especially (20) and (21), there is an implicit direct proportionality relationship between the time of grating and the energy applied during the operation. This is further properly represented in Figure 6.

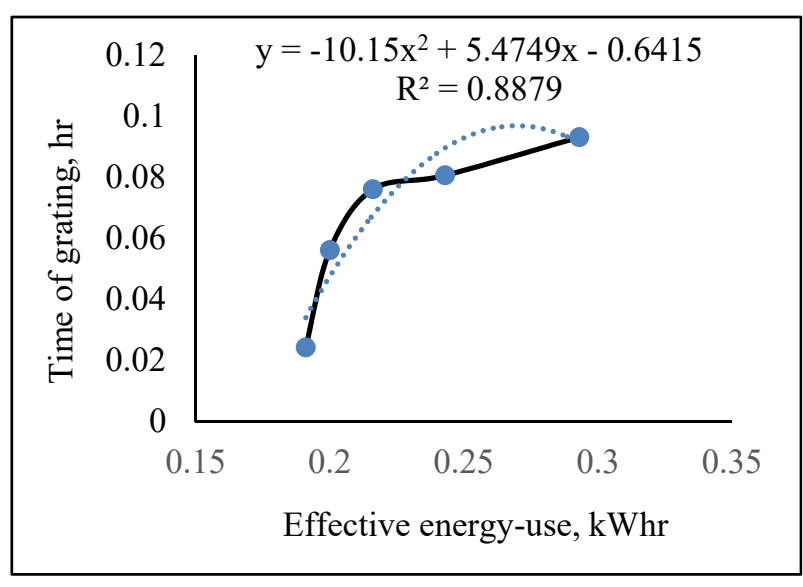

Figure 6. Variation of time of grating with energy-use 


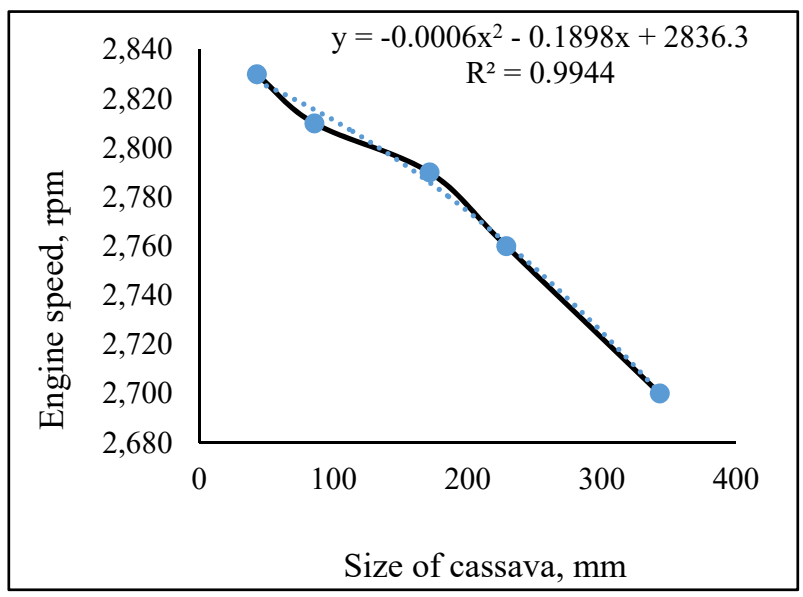

Figure 7. Effect of cassava size on engine speed

Figure 7 shows the relationship between the engine speed and the size of cassava. This is expectedly a polynomial function as in Figure 1, as the engine speed is a major determinant of the power delivered by the engine at constant torque. The size of the cassava affects the speed of the engine and hence the power generated. Notably, however, the engine speed rather varies inversely with the size of the cassava. This indicates that at higher cassava sizes, engine speed was reduced, resulting in a reduction in the entire process speed. In fact, it was observed that the higher cassava sizes caused clogging of the machine and seizure in the rotating grating element.

Figure 8 shows the variation of machine throughput with varying cassava feed sizes.

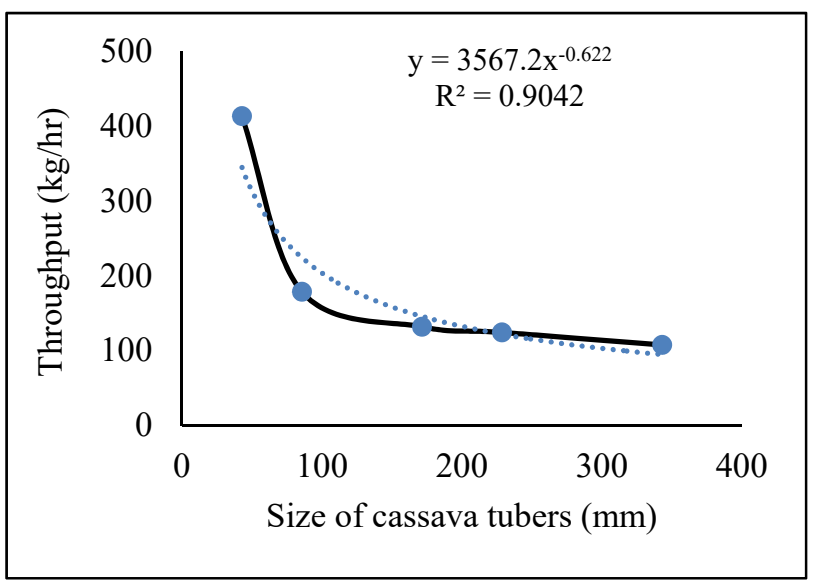

Figure 8. Effect of varying cassava feed size on throughput

The relationship is only best described by a power function (equation 24), indicating that the throughput of the machine in a grating operation geometrically increases at smaller feed sizes of cassava.

$$
M_{t h}=3567.2 C_{s}^{-0.622}
$$

where: $\mathrm{M}_{\mathrm{th}}$ - Machine throughput, $\mathrm{kg} / \mathrm{hr}$

\section{Conclusion}

So much energy is required for the grating of cassava in the production of gari, which is a staple food item in the menu of Nigerians and generally sub-Saharan Africa. This is so because of the effort required in disintegrating the solidly bound particles of the product. In Nigeria, there is difficulty in generating energy for the various operations that need it, of which cassava grating is one. This study has appropriately developed models and estimated energy that would be required for grating cassava of varying feed size dimensions. It concludes that if the original sizes of cassava tubers (i.e. as harvested) are reduced into smaller size dimensions, the energy required would be reduced 
and production would increase. The models formulated here can be used to determine appropriate combinations of cassava size and energy-use for optimization of the grating operation.

\section{References}

Adekanye, T. A., Ogunjimi, S. I., \& Ajala, A. O. (2013). An assessment of cassava processing plants in Irepodun Local Government Areas, Kwara State, Nigeria. World Journal of Agricultural Research, 1(1), 14-17.

Adeniji, A. A., Ega, L. ., Akoroda, M. O., Adeniyi, A. A., Ugwu, B. O., \& De Balogun, A. (2005). Cassava development in Nigeria. Department of Agriculture Federal Ministry of Agriculture and Natural Resources Nigeria. FAO.

Ashaye, O. A., Couple, A. A., Fasoyiro, S. B., \& Adeniji, A. (2005). Effect of location and storage environment on the quality attributes of gari in south-western Nigeria. World Journal of Agricultural Sciences, 1(1), $52-55$.

Bond, F. C. (1952). The Third Theory of Comminution. Transactions of American Institute of Mining Engineers, 193, 484-494.

Cassava, M. (2016). Modern garri processing plant of 2tons/ day. Brunus Enterprises Nigeria Limited. Retrieved from http://cassavamillers.com/studies-and-papers/morden-garri-processing-plant-of-2tons-day

Cock, J. H. (1985). Cassava: New potential for a neglected crop. Colorado, USA: West View Press, 74-91.

Earle, R. L. (1983). Unit operations in food processing. Pergamon Press Limited, Oxford, UK. 207pp.

Food and Agriculture Organisation. (2002). FAOSTAT, Statistical data base of the Food and Agricultural Organization (FAO) of the United Nations. FAO: Rome, Italy.

Hahn, S. K. (1989). An overview of African traditional cassava processing and utilization. Outlook on Agriculture, 18(3), 110-118. http://www.fao.org/wairdocs/ilri/x5458e/x5458e 05.htm

HarvestPlus, (19 March 2012). Minister of Agriculture Launches Vitamin A Cassava in Nigeria. (Challenge Program of the CGIAR). Retrieved 25 September 2013. Retrieved from https://en.wikipedia.org/wiki/Cassava_production_in_Nigeria

Heldman, D. R. (1975). Food processing engineering, AVI Publishing Company Inc., Westport

Henderson, S. M., \& Perry, R. L. (1966). Agricultural process engineering. John Wiley and Sons Inc., New York, 433pp

Howeler, R. R. H., Oates, C. G., \& Allem, A. C. (2001). Strategic environmental assessment: An assessment of the impact of cassava production and processing on the environment and biodiversity. Food and Agricultural Organisation of the United Nations /International Fund for Agricultural Development, Rome, $5(7)$.

Hukki, R. T. (1975). The principles of comminution: An analytical summary; Engineering Mining Journal, 176(May), 106.

Ibrahim, J. S., \& Gaji, M. M. (2016). Energy use patterns of local gari production industries in north central Nigeria. International Journal of Recent Research in Science, Engineering and Technology, 2(2), 131-136. Retrieved from http://www.ijrrset.com

Igoni, A. H. (1991). Design and construction of a continuous-flow rotary-type sieving machine for gari processing. (MSc Thesis of the University of Ibadan), Nigeria. 102.

Igoni, A. H., \& Ayotamuno, J. M. (2016). Maize yield response to induced compaction in a sandy-loam soil. Sustainable Agriculture Research, 5(2), 57-64. http://dx.doi.org/10.5539/sar.v5n2p57

Ilori, T. A. (2001). Sustainable energy development through conservation. Proceedings of the National Engineering Conference and Annual General Meeting of the Nigeria Society of Engineers, 212-219.

Information Nigeria, (4th March, 2016). Power generation now over 4,300 MW. Retrieved from https://www.informationng.com/tag/power-generation. Downloaded May 23, 2016.

International Institute of Tropical Agriculture, IITA. (2013). Overview. Retrieved 25 September 2013. Retrieved from https://en.wikipedia.org/wiki/Cassava_production_in_Nigeria

Jankovic, A., Dundar, H., \& Mehta, R. (2010). Relationships between comminution energy and product size for a magnetite Ore. The Journal of the Southern African Institute of Mining and Metallurgy, 110, 141-146.

Jekayinfa, S. O., \& Olajide, J. O. (2007). Analysis of energy usage in the production of three selected 
cassava-based foods in Nigeria. Journal of Food Engineering, 82, 217-226. Retrieved from

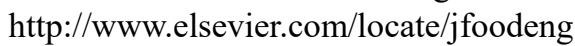

Kick, F. (1885). Das Gesetz Der Proportionalen Widerstande Und Seine Anwendung Felix. Leipzig, Germany.

Knoth, J. (1993). Traditional methods of storage of yams and cassava and its improvement. Deutsche Gesellshaft fur Technische Zusammenarbeit (GTZ) GmbH

Krochmal, A., \& Hahn, S. K. (1991). Tropical root crop in a developing economy: Proceeding of the $9^{\text {th }}$ Symposium of the International Society for Tropical Root Crops, Accra, Ghana.

Kumar, A. (2011). Comminution, Norman B. Keevil Institute of Mining Engineering University of British Columbia Retrieved from http://technology.infomine.com/reviews/comminution/welcome.asp?view=full

Morrell, S. (2004). An alternative energy-size relationship to that proposed by Bond for the design and optimisation of grinding circuits, International Journal of Minerals Processing, 74, 133-141.

Nigeria 2006 Census Figures (Population). What are the population figures of Nigeria for 1996 and 2006. Nigeria/Africa Masterweb Special Feature. Nigeria 2006 Census Figures ... in national controversy and with strong allegations of population inflation. ...www.nigeriamasterweb.com/Nigeria06Cen... Cached. Downloaded May 23, 2016.

Nigeria Population. (2016). Current population of Nigeria - countrymeters. Nigeria Population Clock. Retrieved from http://countrymeters.info/en/Nigeria

Nweke, F. (1992). Processing potential for cassava production growth in Africa. COSCA Working Paper, 11. IITA, Ibadan, Nigeria.

Odigboh, E. U. (1997). Machines for crop production. In B. A. Stout (Ed.), Handbook of Agricultural Engineering - Plant Production Engineering. American Society of Agricultural Engineers.

Opandoh, D. (2014). Standardisation of the grating surface of cassava graters. (MSc Thesis, Department of Agricultural Engineering, Kwame Nkrumah University of Science and Technology), Ghana. p. 68.

Rittinger, R. P. (1867). Lehrbuch Der Aufbereitungskunde. Ernst and Korn, Berlin, Germany.

Sahara Reporters. (2016, March 31). Nigeria's Power Generation Crumbles to Zero Mega Watts for Several Hours.

http://saharareporters.com/2016/03/31/nigerias-power-generation-crumbles-zero-megawatts-several-hours. Downloaded May 23, 2016.

Ugwu, B. O. (1996). Increasing cassava production in Nigeria and prospects for sustaining the trend; Outlook on Agriculture, 25(3), 179-185.

United States Agency for International Development, USAID. (2013). Cassava. Nigeriamarkets.org, USAID. Retrieved 25 September 2013.

Walker, W. H., Lewis, W. K., McAdams, W. H., \& Gilliland, E. R. (1937). Principles of chemical engineering. McGraw-Hill, NY, USA.

Wang, L. J. (2009). Energy efficiency and management in food processing facilities. CRC Press Taylor \& Francis Group, LLC, Boca Raton, FL, USA.

\section{Copyrights}

Copyright for this article is retained by the author(s), with first publication rights granted to the journal.

This is an open-access article distributed under the terms and conditions of the Creative Commons Attribution license (http://creativecommons.org/licenses/by/3.0/). 